\title{
BEDESTENS FROM OTTOMAN PERIOD: FACTORS OF INFLUENCE IMPLEMENTED IN CONTEMPORARY CITY CONCEPT
}

\author{
Prof. Petar Namicev PhD \\ Goce Delchev University - Stip, Republic of Macedonia \\ e-mail:petar.namicev@ugd.edu.mk
}

\section{Original Scientific Paper doi:10.5937/jouproman5-12809}

\begin{abstract}
Bedesten or covered marked, are usually located in the bazaar area of the Balkan city type. Bedesten was served as a place for the transactions of valuable goods, quality fabrics and the shops with luxury items in the past. The analysis of factors are presented at three characteristic preserved bedestens in Bitola, Skopje and Shtip, dating from XV-XVI century.Through presented factors were investigated the impacts of re-building and conservation interventions on the activity of objects in modern urban context, the role of the local community, which affects at the development of cultural tourism,at theambiental values of the environment, raising awareness, identifying and attitude of the population to the monuments. The identification of factors which affecting the modern treatment of historic buildings is important because of their adequate treatment adapted to modern needs, raising of awareness of population and development of cultural tourism.
\end{abstract}

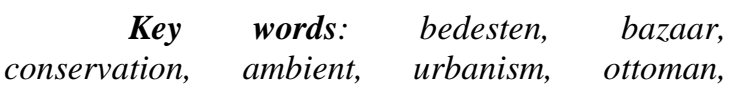
tradition

\section{Introduction}

Bedestens building is part of Ottoman architecture in the period XVXIX th century. Ottoman concept of grouping of public buildings practiced building: a mosque, a hammam, a han and an bedesten in a spatial concept, in their urban (Cipan, 1955). This concept is practiced throughout the Ottoman Empire, and the Balkan cities. Bedesten or covered marked, are usually located in the bazaar area of the Balkan city type. Bedesten was served as a place for the transactions of valuable goods, quality fabrics and the shops with luxury items in the past. The old Bezistan in Skopje was a series of connected streets that housed shops of various craftsmen (Celebija, 1957)
Bedestens in Bitola, Skopje and Stip is one of the most important preserved Ottoman buildings of the present day in Republic of Macedonia, as part of the former Ottoman Empire (Pavlov, 2008). These buildings had modest architectural values with functional values adjusted, usually rectangular or irregularly shaped basically, where are highlighted several entrances to the complex of small commercial spaces. Bedesten space conception can be basilica (Bitola) or multi-domed (Shtip), (Waltenberger, 2014).

Depending on the needs and size of the city and its population they had different sizes, tailored to the needs of the population. At the beginning of their existence they were meant for selling textiles, and later other valuable products, which gradually formed separate rooms for different craft stores.

As complex buildings they were built of solid material, with vaulted domes and arches, covered with lead or copper, closed with iron gates at the entrance (Bogoevic 2014). The interior space has been fitted the square fields, covered with domes or arches (Bitola) (Kocankovska, 2008). From the outside they were clinging stores that were within the city bazaar (Skopje).

The interior space as a single, covered, could if necessary make a by partitions at different times (Stip) (Tomovski, 2006). 
Mostly after more conservation interventions at different times they were functionally integrated in the downtown core, or part of the historic city.

The main direction of research is the analysis of form and treatment of bedestens in the modern urban development of cities. Having regard in particular to analyze their historical development of architectural form through changes occurring in the structure and space, their inclusion in active function of the needs of the city and participation in cultural and tourist development of the settlements.

\section{Purpose of bedestens}

The main function of bezestens since their initial construction is wrapping craftsmen, where they offered their products to a single space or in a complex, as secure building with doors that could be locked by night. (Celebija,1957).
Bedestens in Bitola and Skopje had set aside spaces for specialized trade services of certain kind of products, while Stip Bedesten had single rectangular open space at the beginning for textile products(Fig.1).

Changing the space, with constant interventions of the construction and use of different materials, in different periods they are changing their purpose. These facilities include ambient, have historical, urban, cultural and economic importance. Indigenous values of these buildings are recognizable by the impact with the immediate environment, structural and spatial conception, and with stylistic features that form the outer appearance. Bedestens contain stylistic features of Ottoman Turkish School, through influences from the Byzantine and Oriental architecture, but also elements from the local tradition of building (Waltenberger, 2014).

\begin{tabular}{|c|c|c|c|}
\hline Bedesten & 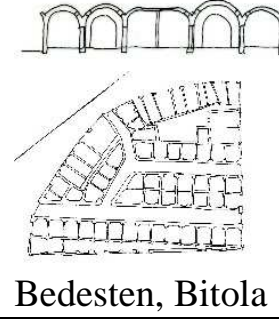 & $\begin{array}{l}{\left[\begin{array}{c}1 \\
\cdots\end{array}\right]} \\
\text { Bedesten, Skopje }\end{array}$ & 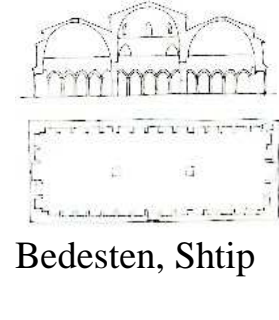 \\
\hline Total space & $1750 \mathrm{~m}^{2}$ & $517 \mathrm{~m}^{2}$ & $477.99 \mathrm{~m}^{2}$ \\
\hline Used space & $637.34 \mathrm{~m}^{2}$ & $159,36 \mathrm{~m}^{2}$ & $386.19 \mathrm{~m}^{2}$ \\
\hline$\%$ & $36,5 \%$ & $30.7 \%$ & $80,7 \%$ \\
\hline Corridors & $587.66 \mathrm{~m}^{2}$ & $195 \mathrm{~m}^{2}$ & I \\
\hline$\%$ & $33.5 \%$ & $37 \%$ & l \\
\hline $\begin{array}{l}\text { Walls/ } \\
\text { construction }\end{array}$ & $525 \mathrm{~m}^{2}$ & $162.24 \mathrm{~m}^{2}$ & $91.8 \mathrm{~m}^{2}$ \\
\hline$\%$ & $30 \%$ & $32,3 \%$ & 19.03 \\
\hline $\begin{array}{l}\text { Number of shops in } \\
\text { bedesten }\end{array}$ & 41 & 17 & One space \\
\hline $\mathrm{m}^{2} / \mathrm{shop}$ & $22-28 m^{2}$ & $7,92-24 \mathrm{~m}^{2}$ & I \\
\hline Inside high & $5,7-6,2 \mathrm{~m}$ & $2,7-5,3 \mathrm{~m}$ & $13,25 \mathrm{~m}$ \\
\hline Citizens XVI-XIX c & $30-50.000$ & $30-32.000$ & $3.800-10.000$ \\
\hline $\begin{array}{l}\text { City bazaar - number of } \\
\text { shops }\end{array}$ & 2.000 & 2.150 & 450 \\
\hline
\end{tabular}

Fig.1. Comparative analysis of architectural space of the bedestens 
The design characteristics of bedestens from their initial forms, constantly havecertain changes, regarding interventions of construction and aesthetic external shape. Still is the basic concept was preserved of application materials (stone, brick and lime mortar), which held the authentic form of construction(Fig.2.).

\begin{tabular}{|l|l|l|}
\hline Bedesten, Bitola & Bedesten, Shtip \\
\hline Brick & Brick, stone & Stone \\
\hline Lime mortar & Lime mortar & Lime mortar \\
\hline Arch & Arch & Dome \\
\hline lead/sheet & lead/ceramide & stone plates XX c. \\
\hline Decorative facade & $/$ & Minimal decorative facade \\
\hline Brick/stone & Brick/stone & Stone \\
\hline Basilica & $/$ & Multi-domed \\
\hline Moisture & Moisture & Moisture \\
\hline
\end{tabular}

Fig.2.Comparative analysis of construction of the bedestens

\section{System of applied protection}

The measures that were taken to protect bedestens realized in the second half of the 20th century and applied basic measures for their conservation. Today, despite their steady state after 30 to 50 years, requires extra care for their continual rehabilitation. Despite this it is necessary to apply measures of preventive care in the process before construction resulted in critical shape.

Depending on the complexity of the structure requires a multivalent approach to determine the protective measures which will largely correspond to the facts.

The original function and condition of the monument changed in continuity till today. Its necessary to undertake complex analyzes and procedures that would satisfy a certain contemporary needs. The direction of interventions should meet the elements as visual recognition, preservation of the vital elements of the building, the comfort of space, integration of the space, improve availability and promotion of the monument in the environment and so on. Existing legislation allows incorporating all aspects and modern scientific methods to improve the condition and treatment of the monument. It is needed to complement the law on protection of monuments that are protected and which are extremely important for the preservation of cultural heritage (Marasovic, 1985).

\section{Factors of influence}

In particular analysis of the factors influencing the success of the integration of bezestens, active in the urban context, we find a group of influential factors:

1. Through a comparative method of analysis of the dimensions and volumes of the bedestens, we can conclude that they do not affect the functional properties of space. New modified concepts are adapted to the needs and within the permissible interventions they respect the basic architectural concept of the Bedesten (Fig.1.). 


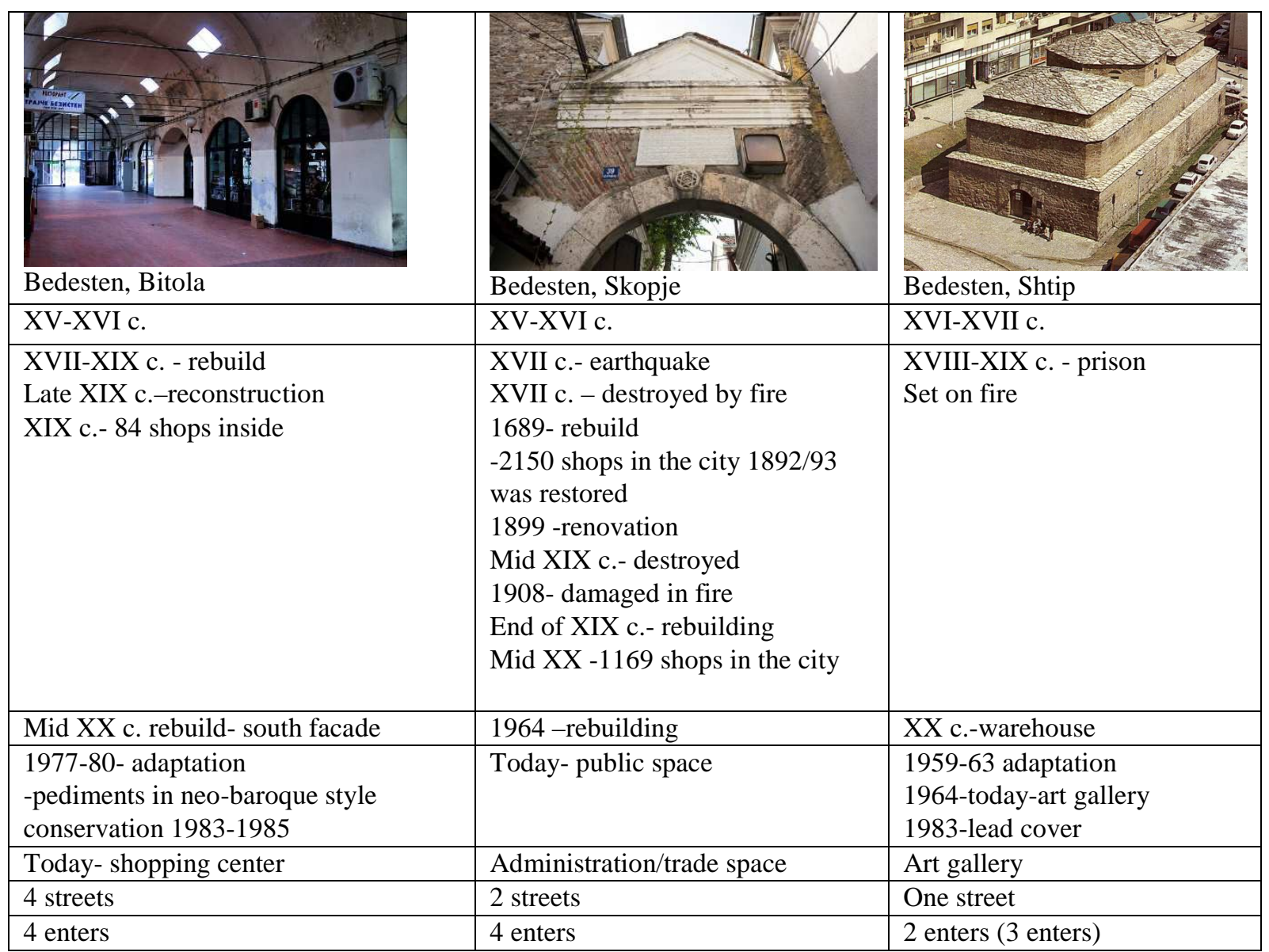

Fig.3. Chronology and conservation of historic buildings - bedestens

2. Bedestens with more height represent attractive spaces, thanks to the applied design, which achieves a significant visual impact. It is important not to disturb the spatial concept of authentic and recognizable appearance(Fig.3.).

3. Due to the historical conditions of their construction periods (15-16 century) and to repeated reconstructions in the 18 th, 19th century (Skopje), the building has been transformed in terms of dimensions, by increasing or decreasing the useful area, based on conditions applied and the means of their construction (Fig.1).

4. Incertain changes to the architectural concept in repeated interventions of the bedestens in 19th and 20th century (Bitola) were observed changes of stylistic features of external decoration. It does not reduce the attractiveness of external decoration (Bitola).

5. Interventionsof preservation over the second half of the 20th century has been influenced the authenticity of space and structure, their structural and aesthetic solidity.To pay special attention of structural stability, consistency of architectural form and complete visual image recognition of the historical style of the bedestens (Fig.3).

6. The attitude of bedestens spatial concept to other historic buildings or historic cores are fostered through respect and adjust to the ambient concept of environment. The relationship of bedestens with the ambient (environment) is very important for its integration into the modern needs of the city (Fig.4). 
7. Beside values of spatial and structural elements is achieved the effect of a harmonious geometric stile, transparency of forms, emphasized the symbolism of certain decorative elements, where the traditional form is expressed by minimalism in decoration, where it receives harmonious aesthetics, which leads to high ambient achieved values (Fig.4.).

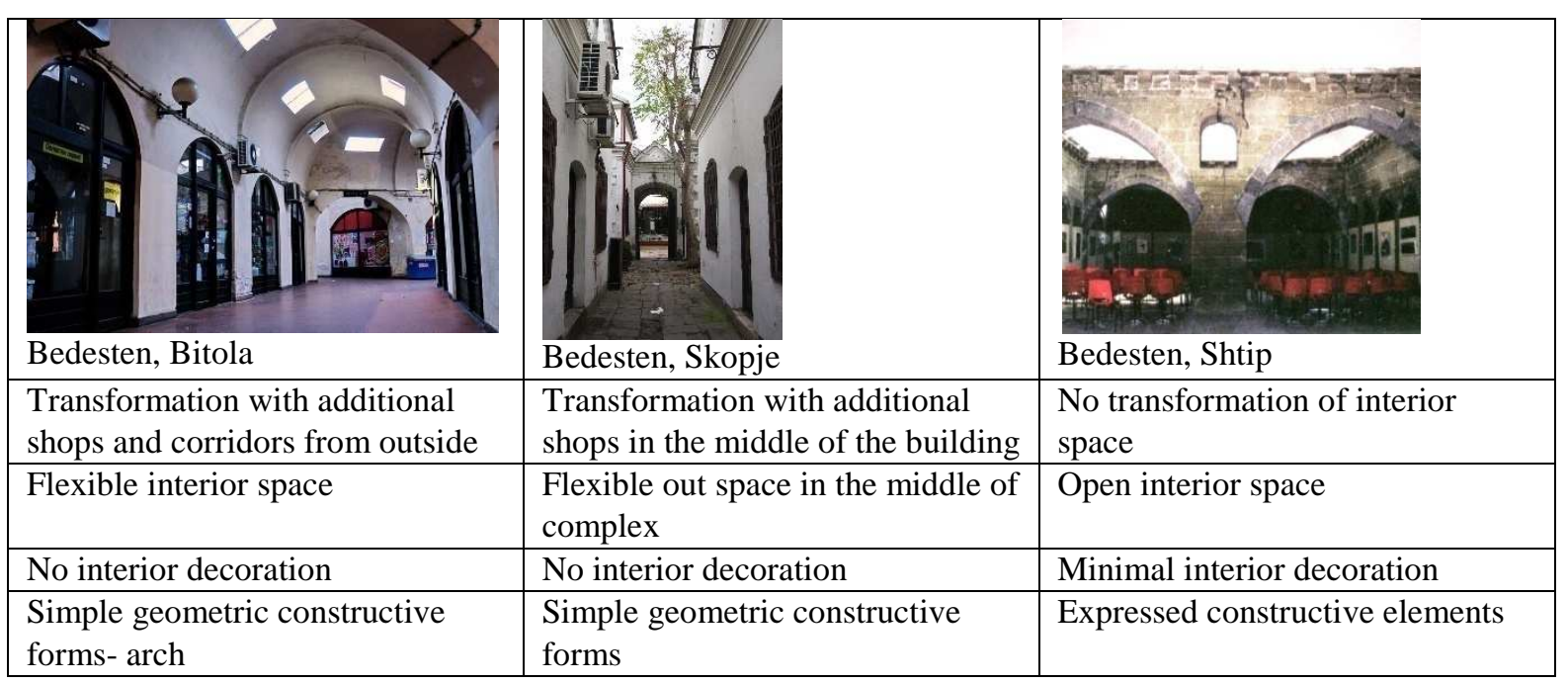

Fig.4. The impact of the internal decoration on the values of the monument

\section{Analysis of further measures}

According to the analysis and methodology of research it is particularly important to determine the priority of factors that lead a certain course of action toward treating bedestens:

1. The essential characteristics of Ottoman buildings need to have authentic historical environment as a factor of guidelines for adaptation and use of their space. By choosing the location, the monument of its existence, gets some recognition of the location. The recognition of the place and its environment depends on the treatment of the monument in a new urban concept arise where relations monument surroundings are transformed and adapted to the contemporary needs. The success of the incorporation of historic buildings in the area is dependent on many factors of urban approach and attitude of the community towards the monument(Fig.5.).

2. Adjustments of space in order to meet the needs of the community while not compromising the protection of the authentic form of the building. Before any work on the monument or the environment, it requires a study of the level of intervention envisaged (in terms of aesthetic form, decoration, interior design, etc.), which should not disrupt certain long-term policy (Fig.4).

3. Ambiental environment has influence, but not mandatory, under the the successful of integration of facilitybedesten in the city core. Surrounding of the monument is a long process that depends on a number of factors in the urban development of the city (Fig.5).

4. The extent of conservation measures taken (an adaptation) affect at the successful of the integration of modern monument to the modern needs of the city. Despite realization of more renovations through the last period (15-19th centuries), recent conservation measures undertaken in the second half of the 20th century, the condition of the buildings is stable (Fig.3.). 


\begin{tabular}{|l|l|}
\hline Bedesten, Bitola & Bedesten, Skopje
\end{tabular}

Fig.5The urban context of the bazaar as a factor of influence

Their need for constant monitoring and taking additional measures is always present and should be included in the annual and long-term municipal planning measures, in order to make their incorporation into modern cultural tourism(Fig.3.).

5. The care for the monument, its maintenance ( construction, aesthetic look, adapting to the needs of the population and so on.) affect to enhance the development of cultural tourism at local and national level.

6. We need to developa sufficient degree of identification of the population and tourists with historic buildings, so they differently affect in particular their affirmation. These facilities fall into the category of important historic buildings in the city, which should represent a solid base for the promotion of certain cultural value of the environment. It is necessary to assess and to take certain actions to implement the concepts of active cultural tourism(Fig.5.).

7. The level of change of the look and layout in different buildings with different extent does that affect the attractiveness. Major interventions are undertaken in a bedesten in Bitola in the 20th century, especially in the second half of the 20th 12 century, in Skopje bedesten with upgrading of the corridor in the middle. Does it affect the attractiveness of the building due to the large functional changes and application of modern materials, which are undermining broadly authenticity of the internal environment and the external appearance(Fig.3.).

\section{Conclusion}

Bedestens had a simple form, using poor construction technique, which to date have managed to maintain their role, based on a building and historic values within the bazaar. Although in certain historical periods, they were destroyed and re-built (Skopje) or stored in the original architectural form, the transformation did not affect their functional purpose, which as an area transformed from open space to space corridors with separately allocated spaces shops.

According to the analysis of factors influencing the urban context of the city, we can conclude that in addition to maintaining the historic buildings in terms of the architecture features, it requires constant adaptation to modern urban concept of the city and the changes that occur. 
Within modern urbanism historic buildings in different ways tailored to contemporary standards of care and their treatment. Thus precautions should be taken into cultural history, economic, climatic, social, urban, tourism and other aspects of modern treatment of bedestens. It requires analysis of the real needs of local government or population to determine strategy towards implementation of methods for activation of historic buildings and space that allows them some useful function.

\section{Reference}

[1] Arsovski, T. (1971): Stara skopska carsija, Skopje, Svetlost

[2] Bogojevic, K. L. (2014): Osmanliski spomenici vo Skopje, Skopje,Tabernakul

[3] Celebija, E. (1957): Putopis, Odlomci o jugoslovenskim zemljama, Sarajevo

[4] Kocankovska, V. (2008): Osvrt vrz izvrsenata revitalizacija na bezistenot vo Bitola, Zbornik Kulturno nasledstvo, 2627/2000-2001, Skopje, 137-169

[5] Krishevljakovik, H. (1954): Nasi bezistani, Zbornik Nase Starine, Sarajevo 233-244

[6] Marasovik, T. (1985): Aktivni pristup graditeljskog nasledja, Split, Sveuciliste u Splitu
[7] Mohammadreza, P. (2014): Role of bazaars as a unifying factor in traditional cities of Iran: The Isfahan bazaar, Frontiers of Architectural research, 3, 10-19

[8] Pavlov, Z., Petkova, R., (2008): Macedonian Cultural heritage: Ottoman monuments, Office in Venice, UNESCO

[9] Stein, C. (2010): Greening Modernism: Preservation, Sustainability, and the Modern Movement, New York, W. W. NORTON \& Company

[10]Tomovski, K., (1967): Adaptacija bezistena u Stipu u galerija slika i skulptura, Zbornik Zastita spomenika kulture, knjiga 18 tom, Beograd, 99-104

[11]Tomovski, K. (2006): Bezisten Stip, Zbornik zastita na spomenicite na kulturata br.2, Skopje, 97-101

[12] Tyler, N., Ligibel, T., and Tyler, I., (2009): Historic Preservation: An Introduction to Its History, Principles, and Practice, 2nd ed. New York, W.W. NORTON \& Co

[13]Cipan, B., (1955): Zastita spomenika kulture u NR Makedoniji, Ansambl Kursumli - hana u Skoplju (han, dzamija, amam), Savezni Institut za zastitu spomenika culture, Zbornik Zastita spomenika kulture IV-V, Beograd, 319-322

[14] Waltenberger, T. (2014): The Ottoman heritage, Architecture in Macedonia, Skopje, LogosA. 